\title{
Performance Characteristics and Nutrient Utilization by Meat Type Chicken Fed Fusarium oxysporum Degraded Brewer Dried Grain
}

\author{
T. E. Lawal ${ }^{1 *}$, F. A. Aderemi ${ }^{1}$, O. M. Alabi ${ }^{1}$, O. A. Oguntunji ${ }^{1}$, M. O. Ayoola ${ }^{1}$, \\ T. P. Olanipekun ${ }^{1}$ and S. G. Ademola \\ ${ }^{1}$ Department of Animal Science and Fisheries Management, Bowen University, Iwo, Nigeria. \\ ${ }^{2}$ Department of Animal Production and Health, Ladoke Akintola University of Science and
} Technology, Nigeria.

\section{Authors' contributions}

This work was carried out in collaboration among all authors. All authors read and approved the final manuscript.

Article Information

DOI: $10.9734 / A R R B / 2020 / v 35 i 1230324$

Editor(s):

(1) Dr. Manikant Tripathi, Dr. Ram Manohar Lohia Avadh University, India.

Reviewers:

(1) Luciano Silva Sena, Federal University of Piauí, Brazil.

(2) Fábio Loures Cruz, Federal University of Lavras, Brazil. (3) Zubair Luqman, Islamia University of Bahawalpur (IUB), Pakistan. Complete Peer review History: http://www.sdiarticle4.com/review-history/59998

Original Research Article

Received 10 June 2020

Accepted 17 August 2020

Published 31 December 2020

\begin{abstract}
The objective of this study was to determine the effect of Fusarium oxysporum degraded Brewer dried grain (BDG) on the performance and nutrient utilization ofbroiler chicken at starter and finisher phases. Undegraded and degraded (BDG) werewas used to compound rations for broiler birds for 8 weeks. The undegraded BDG was used at $7 \%$ inclusion level and the degraded BDG was used at 3 , 5 , and $7 \%$. A total of 150 day old chicks were randomly selected and allocated for 5 treatments. Thirty 30 birds were allocated to each treatment with three replicates each. Fusarium oxysporum was inoculated into BDG through Solid State Fermentation for a period of 7 days. This was used as degraded sample. There was improvement in the crude protein, ash, and gross energy after biodegradation. Biodegradation led to reduction in crude fibre, cellulose, hemicellulose, and detergent fibre content. At starter phase, there were significant $(P<0.05)(P=0.05)$ differences in feed consumption and body weight gain and the highest feed consumption (FC) and body weight
\end{abstract}


gain (BWG) were found in treatment 5, which contained 7\% degraded BDG (DBDG) and the FC and BWG they were 88.93 and $41.07 \mathrm{~g} / \mathrm{bird} /$ day, respectively. At the finisher phase, there were significant $(P=0.05)$ differences in both the average feed intake and the average body weight gain by the birds. The highest feed intake was found in treatment $5(140 \mathrm{~g} / \mathrm{b} / \mathrm{d})$ and the highest body weight gain was also observed in treatment $5(78.21 \mathrm{~g} / \mathrm{b} / \mathrm{d})$. Significant differences $(P=0.05)$ were also observed for the feed conversion ratio at the finisher phase. The best value (1.64) was recorded at the control treatment and this was followed by the value recorded for treatment 5 (1.79). The relative cost benefits revealed that it is profitable to feed broilers with $\mathrm{F}$. oxysporum degraded BDG. The results showed that $F$. oxysporum was able to enhance the feeding value of BDG and this impacted positively on the feed consumption and body weight gain by the birds.

Keywords: Biodegradation; brewer dried grains; broilers; Fusarium oxysporum.

\section{INTRODUCTION}

Low poultry production cost can be achieved if the use of unconventional agro-industrial byproducts (AIBs) agro-industrial by-products is put into consideration. The ever widening competition between humans and livestock is the cause of unabated increase in the cost of conventional feed ingredients. This, undoubtedly, affects the cost of feeding and many farmers may not be able to afford it. Researchers are therefore challenged to find alternatives to these conventional ingredients. So far, the considered alternatives are the agro-industrial by-products.

(AIBs)(AIBs) are obtained from agricultural products after the main products have been obtained.They $[1,2]$. AIBs are the most abundant renewable resources on earth and they are considered because they are available and inexpensive. Furthermore, it is pertinent to consider the use of AIBs because they are beginning to constitute environmental nuisance in some cases. Hence, recently there has been a great campaign for the exploitation of these wastes as low cost materials for the production of microbial enzymes through the instrumentality of solid state fermentation or submerged fermentation techniques.

AIBs cannot be added in high levels because of their low energy content, high fibre content and poor availability of nutrients owing to non-starch polysaccharides content which can account for about $70-90 \%$ of the cell wall $[3,4,5]$. The primary challenge about the use of these unconventional ingredients is the high level of fibre present in them. The presence of the fibre does not make the content to be readily digested by the monogastric animals. Although the animals' innate enzyme production is enough to handle normal digestive activities, the presence of high fibre content and lack of sufficient microorganisms in the gastrointestinal tract make the digestion difficult. The external processing of these non-conventional ingredients consists of enhancing and breaking complex contents like lignin, cellulose, and hemicellulose present in their respective plant cell walls.

It has been shown that after processing (chemical, physical or biological); there tend to be an improvement in the nutritional quality of such materials which invariably leads to increase in productivity of the animals. Brewers' grains are the solid residue remaining after the processing of dried cereal grains for the production of beer and other malt products. Though barley is the major cereal that is being used for brewing, beers can also be made from other cereals such as: wheat, maize, rice, and sorghum. Brewers' grains are obtained at the end of the brewing process [6].

The objectives of this study include: Assessment of the effect of Fusarium oxysporum in degrading brewer dried grain; assessment of the effect of feeding degraded brewer dried grain on the performance of broilers; and assessment of the effect of degraded brewer dried grain on the nutrient utilization by broilers.

\section{MATERIALS AND METHODS}

The used BDG were obtained from a brewery located in Ibadan, Nigeria. It was dried to constant weight at $60^{\circ} \mathrm{C}$. A total of $25 \mathrm{~kg}$ of the dried BDG were autoclaved at $121^{\circ} \mathrm{C}$ for 15 minutes. The autoclaved BDG was then inoculated with $F$. oxysporum under aseptic condition after adjusting its moisture level to $25 \%$. After 7 days, the biodegradation reaction was stopped and the material was dried [7]. Samples were then withdrawn for proximate analysis using the method of [8]. The $F$. oxysporum used was obtained from Microbiology 
Unit of Department of Biological Sciences of Bowen University, Iwo, Nigeria. The characterization of the obtained $F$. oxysporum was known by the use of manual of [9]. A total of 150 day old broiler chicks (Anak strain) were used for the experiment. There were five dietary treatments of 30 birds each and three replicate of 10 birds each. Diet 1 (control) contained neither degraded nor undegraded BDG. Diet 2 contained $7 \%$ undegraded BDG, whereas diets 3, 4, and 5 contained 3,5 , and $7 \%$ levels of $F$. oxysporum degraded BDG, respectively. The experimental design used was Completely Randomized Design. Data were analyzed statistically using the Analysis of Variance (ANOVA) technique of [10]. Where statistical significant differences were observed, the treatment means were compared according to [11].

\section{RESULTS AND DISCUSSION}

Results of improvements in the levels of crude fibre, gross energy, crude protein, detergent fibres, and ash in BDG after biodegradation with F. oxysporum are shown in Table 1. It was observed, after fungal biodegradation that there were positive changes in crude protein value from 26.11 to $32.11 \mathrm{~g} / 100 \mathrm{gDM}(22.98 \%)$. The ash content increased from 9.94 to $12.51 \mathrm{~g} / 100 \mathrm{gDM}$ which were $25.86 \%$. It was noted that the detergent fibre and the crude fibre content of the BDG reduced after biodegradation. The cellulose, acid detergent lignin, and crude fibre had $15.25,14.71 \%$, and $38.87 \%$ reduction, respectively, after biodegradation.

At the starter phase, body weight gain and feed intake were significantly $(P=0.05)$ affected. The relative cost benefit revealed that the birds fed DBDG gave better profit margin than the ones fed UBDG. At the finisher phase, the performance of the birds showed that there were significant $(P=0.05)$ differences in body weight gain, feed intake, and feed conversion ratio. Besides, the profitability of placing the birds on DBDG was shown by the relative cost benefit as the birds placed on DBDG showed better profit margins. Fungal biodegradation of fibrous agroindustrial by-products has been earlier reported by $[12,13,14,15]$. The previous work of [16]

Table 1. Proximate and detergent fibre analysis of undegraded and degraded brewer dried grain (g/100 gDM)

\begin{tabular}{lll}
\hline Parameter & Undegraded BDG & Degraded BDG \\
\hline Dry matter & 90.95 & 88.78 \\
Crude protein & 26.11 & 32.11 \\
Ether extract & 6.83 & 4.39 \\
Ash & 9.94 & 12.51 \\
Crude Fibre & 16.13 & 9.86 \\
Gross Energy (Kcal/kg) & 4.81 & 5.91 \\
Cellulose & 7.21 & 6.11 \\
Hemicellulose & 5.80 & 4.41 \\
Neutral detergent fibre & 2.43 & 1.30 \\
Acid detergent fibre & 2.24 & 1.96 \\
Acid detergent lignin & 6.12 & 5.22 \\
\hline
\end{tabular}

Table 2. Performance of broiler starter fed diets containing undegraded and degraded brewer dried grain

\begin{tabular}{lllllll}
\hline Parameter & Control & 7\%UBDG & 3\%DBDG & 5\%DBDG $^{\text {7\%DBDG }}$ & SEM \\
\hline Body weight gain (g/b/d) & $37.5^{\mathrm{c}}$ & $38.92^{\mathrm{b}}$ & $39.64^{\mathrm{b}}$ & $40.56^{\mathrm{a}}$ & $41.07^{\mathrm{a}}$ & 1.10 \\
Feed intake (g/b/d) & $81.79^{\mathrm{b}}$ & $78.57^{\mathrm{c}}$ & $87.5^{\mathrm{a}}$ & $88.21^{\mathrm{a}}$ & $88.93^{\mathrm{a}}$ & 2.21 \\
Feed conversion ratio & 2.18 & 2.01 & 2.20 & 2.19 & 2.16 & 0.051 \\
Mortality (\%) & 0 & 0 & 1 & 1 & 0 & - \\
Relative cost benefit (\%) & 0.00 & 3.85 & 3.90 & 4.22 & 4.42 & - \\
\hline
\end{tabular}

$a, b, c$, Means in the same row with different superscripts differ significantly $(P<0.05) ;$ UBDG= Undegraded brewer dried grains; $D B D G=$ degraded brewer dried grains. SEM $=$ Standard Error of Mean 
showed improvement in the nutritional value of plantain wastes via the activities of fungi using solid state fermentation technique. These authors reported that ripe plantain peels and unripe plantain peels were subjected to biodegradation using $A$. niger, $A$. flavus, and Penicillium spp. After 7 days of fermentation, $A$. niger, A. flavus, and Penicillium spp. increased the crude protein content of the unripe plantain peel by $34.00,30.30$, and 2.30 and ripe plantain by $9.50,4.50$, and $4.00 \%$, respectively. A. niger and $A$. flavus grown on pineapple wastes produced similar results and there was reduction in cellulose and crude fibre contents [17]. In the earlier works of [7], the authors reported that over $35 \%$ of the original cellulose content of the substrate was lost during solid-state fermentation. Dhanasekeran and Paneerselvam (2011) also opined that fungi have the ability to produce a variety of enzymes and that cellulase, hemicellulase, pectinase, and xylanases among others were produced by fungi, which could degrade the non-starch polysaccharides (NSPs) in the substrate. The cell contents of AlBs are digestible but for the cell walls which consist primarily of cellulose and hemicellulose. In addition, the AlBs are poorly digested also because they are highly lignified. The improvement in crude protein value of the DBDG may be due to the ability of $F$. oxysporum (like other fungi earlier mentioned) to release multiple enzymes during biodegradation which will break the plant cell wall and hence the release of the hidden proteins in the cells. The improvements may also be due to the addition of single cell protein by the biodegradation agent $F$. oxysporum [18]. Improvement in the energy availability in DBDG may be due to ability of the $F$. oxysporum to dismantle the starch and the non-starch polymers into monomer sugars $[13,19]$. The gross energy in DBDG increased after biodegradation possibly because of the oxidation of the ether extract. Lipids when oxidized have the ability to yield tremendous quantity of energy. Performance characteristics revealed better weight gain by the birds placed on DBDG than those placed on UBDG at both starter and finisher phases. The breaking down of NSPs contained in the BDG may be responsible for this. NSPs have been reported to increase viscosity of digestive content and this will negatively affect digestion of the feed and bioavailability of the nutrient content. The NSPs can make nutrients complex, thereby obstructing their absorption and the complete utilization of the diets. The performance of the birds was better at the finisher phase, possibly due to a better utilization of nutrients as the birds increased in age. In the works of [20], it was reported that inclusion level of agro-industrial by products in animal's diet is determined by some factors which are: the quality and digestibility of the materials, the species of the animals, and the age of the animals. It can also be seen from Tables 2 and 3 that the feed intake of the birds increased with their age. The older the birds, the more quantity of feed they consumed. In Tables 6 and 7, it was observed that there were significant $(P=0.05)$ differences in the digestibility of ether extract, crude protein, crude fibre, ash, and dry matter at both starter and finisher phases. The use of fungi to improve the digestibility of high fibrous materials has been documented by [21]. The author observed that with increment of cellulose level in diet, there was a great reduction in the digestibility and hence reduction in metabolizable energy values.

It was also reported by the author that the efficiency of utilization of metabolizable energy by broilers decreased with increasing cellulose in the diets. Besides, it was also submitted that feed utilization decreased as fiber level increased and as a result of these, energy utilization also

Table 3. Performance of broiler finishers fed diets containing undegraded and degraded brewer dried grain

\begin{tabular}{lllllll}
\hline Parameter & Control & 7\%UBDG & 3\%DBDG & 5\%DBDG & 7\%DBDG & SEM \\
\hline Body weight gain (g/b/d) & $72.14^{\mathrm{d}}$ & $72.50^{\mathrm{d}}$ & $74.64^{\mathrm{c}}$ & $76.78^{\mathrm{b}}$ & $78.21^{\mathrm{a}}$ & 2.24 \\
Feed intake (g/b/d) & $118.57^{\mathrm{d}}$ & $119.29^{\mathrm{d}}$ & $126.79^{\mathrm{c}}$ & $133.93^{\mathrm{b}}$ & $140.00^{\mathrm{a}}$ & 4.24 \\
Feed conversion ratio & $1.64^{\mathrm{c}}$ & $1.65^{\mathrm{c}}$ & $1.70^{\mathrm{b}}$ & $1.74^{\mathrm{a}}$ & $1.79^{\mathrm{a}}$ & 0.014 \\
Mortality (\%) & 0 & 1 & 1 & 1 & 0 & - \\
Relative cost benefit (\%) & 0.00 & 3.14 & 3.56 & 4.22 & 4.55 & - \\
\hline a, b, c, Means in the same row with different superscripts differ significantly (P<0.05); UBDG=undegraded brewer dried \\
\multicolumn{7}{c}{ grains; DBDG=degraded brewer dried grains } \\
SEM = Standard Error of Mean
\end{tabular}


Table 4. Composition of experimental diet at starter phase

\begin{tabular}{|c|c|c|c|c|c|}
\hline Ingredients & Control & $7 \%$ UBDG & $3 \%$ DBDG & $5 \%$ DBDG & $7 \%$ DBDG \\
\hline Maize & 54 & 56 & 53 & 54 & 54 \\
\hline UBDG & - & 7.0 & - & - & - \\
\hline DBDG & - & - & 3.0 & 5.0 & 7.0 \\
\hline Wheat offal & 5.2 & 0.3 & 2.3 & 2.3 & 2.3 \\
\hline Groundnut cake & 11.1 & 15 & 15 & 12 & 11 \\
\hline Soya bean meal & 20 & 12 & 17 & 17 & 16 \\
\hline Fish meal & 6 & 6 & 6 & 6 & 6 \\
\hline Bone meal & 2 & 2 & 2 & 2 & 2 \\
\hline Oyster shell & 1 & 1 & 1 & 1 & 1 \\
\hline Premix & 0.25 & 0.25 & 0.25 & 0.25 & 0.25 \\
\hline Salt & 0.25 & 0.25 & 0.25 & 0.25 & 0.25 \\
\hline Lysine & 0.10 & 0.10 & 0.10 & 0.10 & 0.10 \\
\hline Methionine & 0.10 & 0.10 & 0.10 & 0.10 & 0.10 \\
\hline Total & 100 & 100 & 100 & 100 & 100 \\
\hline Metabolizable energy & 2912.34 & 2958.71 & 2874.47 & 2906.52 & 2890.03 \\
\hline Crude protein & 23.20 & 23.43 & 22.68 & 22.70 & 22.36 \\
\hline
\end{tabular}

Table 5. Composition of experimental diet at finisher phase

\begin{tabular}{llllll}
\hline Ingredients & Control & $\mathbf{7 \% U B D G}$ & 3\%DBDG & 5\%DBDG & 7\%DBDG \\
\hline Maize & 54 & 57 & 56 & 57 & 57 \\
UBDG & - & 7.0 & - & - & - \\
DBDG & - & - & 3.0 & 5.0 & 7.0 \\
Wheat offal & 12.4 & 6.5 & 11.0 & 9.1 & 6.5 \\
Groundnut cake & 10.2 & 10.2 & 10.2 & 10.2 & 10.2 \\
Soya bean meal & 16.7 & 12.6 & 13.1 & 12 & 12.6 \\
Fish meal & 3 & 3 & 3 & 3 & 3 \\
Bone meal & 2 & 2 & 2 & 2 & 2 \\
Oyster shell & 1 & 1 & 1 & 1 & 1 \\
Premix & 0.25 & 0.25 & 0.25 & 0.25 & 0.25 \\
Salt & 0.25 & 0.25 & 0.25 & 0.25 & 0.25 \\
Lysine & 0.10 & 0.10 & 0.10 & 0.10 & 0.10 \\
Methionine & 0.10 & 0.10 & 0.10 & 0.10 & 0.10 \\
Total & 100 & 100 & 100 & 100 & 100 \\
Metabolizable energy & 2904.44 & 2998.20 & 2911.72 & 2928.09 & 2947.24 \\
Crude protein & 20.57 & 20.36 & 20.55 & 20.29 & 20.51 \\
\hline
\end{tabular}

$U B D G=$ undegraded brewer dried grains; $D B D G=$ degraded brewer dried grains. *Vitamin mineral premix supplied the following vitamins and trace elements per kg diet: Vit. A 12500IU, Vit. $D_{3} 2500 \mathrm{IU}$, Vit. E $40 \mathrm{mg}$, Vit. $K_{3} 3 \mathrm{mg}$, Vit. $B_{1} 3$ $\mathrm{mg}$, Vit. $B_{2} 5.5 \mathrm{mg}$, Niacin $5.5 \mathrm{mg}$, Calcium Pantothenate $11.5 \mathrm{mg}$, Vit $B_{6} 5 \mathrm{mg}$, Vt $B_{12} 0.025 \mathrm{mg}$,

Folic Acid $1 \mathrm{mg}$, Biotin $0.08 \mathrm{mg}$, Mn $120 \mathrm{mg}$, Choline Chloride $500 \mathrm{mg}$, Fe $100 \mathrm{mg}$, Zn $80 \mathrm{mg}$, Cu 8.5mg,

I $1.5 \mathrm{mg}$, Co $0.3 \mathrm{mg}$, Se $0.48 \mathrm{mg}$ and Antioxidant $120 \mathrm{mg}$

Table 6. Nutrient digestibility of experimental broilers at starter phase

\begin{tabular}{lllllll}
\hline Composition (\%) & Control & $\mathbf{7 \% U B D G}$ & $\mathbf{3 \% D B D G}$ & $\mathbf{5 \% D B D G}^{2}$ & $\mathbf{7 \% D B D G}$ & SEM \\
\hline Ether extract & $61.11^{\mathrm{a}}$ & $51.63^{\mathrm{c}}$ & $55.35^{\mathrm{c}}$ & $54.55^{\mathrm{c}}$ & $57.09^{\mathrm{b}}$ & 2.02 \\
Crude protein & $72.35^{\mathrm{c}}$ & $72.70^{\mathrm{c}}$ & $75.77^{\mathrm{b}}$ & $78.39^{\mathrm{a}}$ & $79.00^{\mathrm{a}}$ & 1.93 \\
Crude fibre & $58.43^{\mathrm{d}}$ & $60.31^{\mathrm{c}}$ & $62.22^{\mathrm{b}}$ & $64.11^{\mathrm{b}}$ & $66.12^{\mathrm{a}}$ & 1.54 \\
Ash & $35.56^{\mathrm{c}}$ & $34.44^{\mathrm{c}}$ & $38.21^{\mathrm{b}}$ & $38.01^{\mathrm{b}}$ & $44.91^{\mathrm{a}}$ & 1.23 \\
Dry matter & $70.84^{\mathrm{b}}$ & $71.29^{\mathrm{b}}$ & $71.15^{\mathrm{b}}$ & $71.46^{\mathrm{b}}$ & $72.33^{\mathrm{a}}$ & 2.45 \\
\hline
\end{tabular}

$a, b, c$, Means in the same row with different superscripts differ significantly $(P<0.05)$; UBDG=undegraded brewer dried grains; $D B D G=$ degraded brewer dried grains 
Table 7. Nutrient digestibility of experimental broilers (finisher phase)

\begin{tabular}{|c|c|c|c|c|c|c|}
\hline Composition (\%) & Control & $7 \%$ UBDG & 3\%DBDG & 5\%DBDG & 7\%DBDG & SEM \\
\hline Ether extract & $62.49^{b}$ & $60.07^{c}$ & $63.53^{c}$ & $65.41^{\mathrm{b}}$ & $69.92^{a}$ & 2.12 \\
\hline Crude protein & $63.95 b^{c}$ & $63.35^{c}$ & $64.29^{b}$ & $65.15^{\mathrm{b}}$ & $67.07^{a}$ & 1.45 \\
\hline Crude fibre & $62.45^{\mathrm{d}}$ & $65.56^{c}$ & $66.61^{\mathrm{c}}$ & $68.33^{b}$ & $71.31^{a}$ & 1.31 \\
\hline Ash & $46.08^{b}$ & $44.01^{c}$ & $45.45^{\mathrm{b}}$ & $49.97^{b}$ & $48.79^{a}$ & 1.12 \\
\hline Dry matter & $69.52^{\mathrm{C}}$ & $66.81^{d}$ & $70.25^{\mathrm{b}}$ & $70.21^{b}$ & $72.75^{\mathrm{a}}$ & 2.34 \\
\hline
\end{tabular}

decreased. Furthermore, it was shown to improve nutrient digestibility, destroy antinutritional factors, and manipulate gut flora population. In the work of another author [12], it was reported that the better utilization of nutrients could also be attributed to increase in bioavailability of nutrients present within the cells and possibly elimination of the anti-nutritional factors and reduction in intestinal viscosity after fungal biodegradation. The improvement in the various nutrient digestibilities shows that biodegradation of BDG provided the birds free access to the nutrients trapped within the cells and allows maximum utilization for the birds.

\section{CONCLUSION}

The improvement in the birds' performance may possibly be attributed to the effect of biodegradation process on the fibrous BDG. In addition, the synergistic activities of the cocktail of enzymes produced by $F$. oxysporum during the biodegradation process led to positive modification of the BDG, which subsequently affected the performance of the birds. There were improvements in the body weight gain, feed intake, feed conversion ratio, and relative cost benefits. These would make broiler production a profitable business for farmers. This generally shows that solid state fermentation or inclusion of brewer dried grains degraded with $F$. oxysporum can positively affect the performance of broiler birds and that fungal biodegradation is beneficial to the poultry industry.

\section{ETHICAL APPROVAL}

Animal Ethic committee approval has been taken to carry out this study.

\section{COMPETING INTERESTS}

Authors have declared that no competing interests exist.

\section{REFERENCES}

1. Rizal Y, Mahatam E, Joli I, Wu G. Improving Trichoderma viride for poultry Diet. Pak. J. Nutr. 2012;(11):203207.

2. Aderolu AZ, lyayi EA, Onilude AA. Changes in nutritional value of rice husk during Trichoderma viride degradation. Bulg. J. Agri. Sci. 2007;(13): 583-589.

3. Suranindyah Y, Astuti A. The effects of feeding dried fermented cassava peel on milk production and composition of Etawah crossedbred goat. World Acad. Sci. Eng. Tech. 2012;(70):10-21.

4. Hilda G, Nufez G, Sergio J, Gomex R, Carlos E, Esquivet GE, Bernah GNA, Campos RM. Isolation of Native strains of Trichoderma spp from horticultural soils of the valley of Toluca, for potential biocontrol of Sclerotina. Trop. Subtrop. Agro Ecosys. 2012;(15):357-362.

5. Onyimba IA, Ogbonna CIC, Akuneshi CO, Chukwu CO, Ogbonna Al. Microbial processing of spent sorghum grains for possible use as chicken feed. ISOR J. pharm. Biol. Sci. 2014;(9):34-37.

6. Perez-Mendoza V, Jacobs C, Parsons C, Barnes J, Kuhlenschmidt J, Jenkins J, Pettigrew J. Changes in gut microbiota of broiler chicks fed distillers dried grains with soluble (DDGS) during a coccidial infection. J. Anim. Sci. 2009;(2):63-87.

7. Iyayi EA, Losel DM. Changes in carbohydrates fractions of cassava peel following fungal solid state fermentation. J. Food Tech. Afr. 2001; 6(3):101-103.

8. AOAC. Official Methods for Analysis: Association of Official Analytical Chemists. $\left(18^{\text {th }}\right.$ edition) Washington D.C. U.S.A; 2008.

9. Barnett HL. Illustrated genes of imperfect fungi. Minnesota: Burgess Publishing Company; 1992. 
10. Steel RGD, Torrie JH. Principles and Procedures of statistics. New York, Toronto, London, Mc Graw Hill Book Company, Inc; 1990.

11. SAS Institute in C. SAS/STAT. SAS Institute Inc. Cary, NC USA; 1999.

12. Kayode RMO, Sani A, Apata DF, Joseph JK, Annongu AA, Kolawole OM, Awe SM, Obalowu MA. Performance and carcass characteristics of broiler chickens fed on fungal mixed-culture (Aspergillus niger and Penicillium chrysogenum) fermented mango kernel cake. Global Res. J. Microbiol. 2012;2(1):67-75.

13. Lawal TE, Alabi OM, Ademola SG, Alagbe IA, Adebiyi OA. Fungal biodegradation of plantain (Musa paradisacal) peel through solid state fermentation for broiler finisher Feeding: In vitro digestibility, performance, haematological and serum parameters. Elixir Biotech. 2012;(49):10079-10083.

14. Iyayi E A, Aderolu ZA. Enhancement of the feeding value of some agro industrial by products for laying hens after their solid state fermentation with Trichoderma viride. Afr. J. Biotechnol. 2004;3(3):182-185.

15. Egwim EC. Production of animal feed concentrates from sour sop and pineapple peels using solid state fermentation. J. Biol. Agri. Healthcare. 2014;4(22):22-29.

16. Akinyele BJ, Agbro $O$. Increasing the nutritional value of plantain wastes by the activities of fungi using the solid state fermentation technique. Res. J. Microbiol. 2014;2(2):117-124.

17. Hamlyn PF. Fungal biotechnology. Brit. Mycological society newsletter; 1998.

18. Iyayi EA. Changes in the cellulose, sugar and crude protein contents of agroindustrial by-products fermented with Aspergillus niger, Aspergillus flavus and Penicillium sp. Afr. J. Biotechnol. 2004;3 (3):186-188.

19. Alabi OO, Atteh JO. Efficacy of supplementary enzymes on in vitro digestibility of various ratios of maize with wheat offal. Scientific J. Anim. Sci. 2012; 1(4):142-145.

20. Lawal TE, lyayi E A, Adeniyi BA, Adaramoye OA. Extraction of Enzymes from four Fungi and their use to improve the nutritive value of Groundnut Pod for Broiler feeding. Int. J. Poult. Sci. 2010;9: 340-346.

21. Begin JJ. A composition of calculated and determined M.E of some feed ingredients. J. Nutr. 2001;(34):12-19.

(c) 2020 Lawal et al.; This is an Open Access article distributed under the terms of the Creative Commons Attribution License (http://creativecommons.org/licenses/by/4.0), which permits unrestricted use, distribution, and reproduction in any medium, provided the original work is properly cited.

Peer-review history:

The peer review history for this paper can be accessed here: http://www.sdiarticle4.com/review-history/59998 